Original Research Paper

\title{
Inclusion of Molasses or Glucose Syrup in Starter Concentrate for Dairy Calves: Effects on Diarrheic Calves
}

\author{
${ }^{1}$ Marcelo Cezar Soares, ${ }^{2}$ Carlos Eduardo Oltramari, ${ }^{1}$ Marília Ribeiro de Paula, \\ ${ }^{3}$ Carolina Corrêa de Figueiredo Monteiro, ${ }^{1}$ Gerson Barreto Mourão and ${ }^{1}$ Carla Maris Machado Bittar \\ ${ }^{1}$ Universidade de São Paulo/ESALQ. Av. Pádua Dias, 11. CEP 13418-900. Piracicaba, SP, Brazil \\ ${ }^{2}$ Universidade Estadual de Santa Catarina- UDESC, Rua BeloniTrambeta Zanin, 680. 89.815-630, Chapecó, SC, Brazil \\ ${ }^{3}$ Universidade Federal Rural de Pernambuco. Rua Manoel de Medeiro, S/N.52171-900. Dois Irmãos, Recife-PE, Brazil
}

\section{Article history}

Received: 11-12-2015

Revised: 27-01-2016

Accepted: 26-03-2016

Corresponding Author:

Carla Maris Machado Bittar

Universidade de São

Paulo/ESALQ. Av. Pádua Dias,

11. CEP 13418-900. Piracicaba,

SP, Brazil

Email: carlabittar@usp.br

\begin{abstract}
Severity of metabolic acidosis and other clinical signs in diarrheic dairy calves fed a starter concentrate containing molasses or glucose syrup as a replacement for corn were evaluated. Thirty-two calves were blocked according to birth weight and were divided into four treatments according to starter concentrate composition: (1) Control, starter concentrate based on corn; (2) $5 \%$ of molasses as a replacement for corn; (3) $10 \%$ of molasses as a replacement for corn; (4) $5 \%$ glucose syrup as a replacement for corn. Animals were individually housed with free access to water and concentrate and received $4 \mathrm{~L} / \mathrm{d}$ of milk replacer. Blood samples were analyzed and evaluations of fecal score, clinical score and physiological parameters were performed during the first three days of all diarrhea event. Starter concentrate composition did not negatively affect $(p>0.05)$ fecal scores or diarrhea clinical signals. Blood gas, electrolytic and biochemical analyses do not indicated hydration, acidosis, or other metabolic disorders $(\mathrm{p}>0.05)$. However, higher level of molasses increased hematocrit $(p<0.04)$, suggesting higher dehydration condition. Inclusion of these by products as a replacement for corn in the concentrate did not alter the animals' metabolism in response to the occurrence of diarrhea and can therefore be utilized in the feed without causing damage to the animal's health.
\end{abstract}

Keywords: By-Products, Calf, Concentrate, Diarrhea, Dehydration

\section{Introduction}

The inclusion of by products in the starter concentrate has been utilized as a strategy to reduce costs associated with feeding dairy replacement heifers. However, the use of byproducts for young calves feeding may present negative factors since these animals are still in the process of developing their rumen (Lesmeister et al., 2004) and have a reduced ability to efficiently use some nutrients. This lower ability may cause an increase in the incidence and/or severity of diarrhea, thereby resulting in worsening of clinical metabolic disorders.

Molasses has been included in starter concentrates not only to act as a less costly source of readily fermentable carbohydrate, but also because it essentially consists of soluble sugars (mainly sucrose) and minerals (NRC, 2001). Moreover, the liquid molasses is utilized as a resource to improve acceptability and to give better consistence to the diet by agglomerating the powder. Commonly, the inclusion of molasses in the starter concentrate of calves is performed at levels between 3 and 12\%. According to Lesmeister and Heinrichs (2005), the inclusion of $12 \%$ molasses on a DM basis in the starter concentrate did not result in significant differences in Body Weight (BW) of animals, Dry Matter Intake (DMI), Average Dailygain (ADG) or feed efficiency during the liquidfeeding period as compared to the control group that received 5\% molasses. However, after the liquidfeeding period, the inclusion of molasses, mainly at the inclusion rate of $12 \%$ on a total dry matter basis, reduced the total DMI and ADG.

Glucose syrup can also be utilized to increase acceptability and to provide highly ferment a table carbohydrates. It has a dry matter content greater than 
$70 \%$, dextrose no less than $20 \%$ DM and sulfate no more than $1 \%$ DM. Studies that evaluate the supply of starter concentrate containing different levels of inclusion of molasses and glucose syrup for newborn calves are scarce. During the first weeks of life, calves are very susceptible to gastrointestinal diseases since they are not able to digest some types of feed due to the absence or low production of certain enzymes and also due to the poor presence of developed microflora in the digestive tract (Toullec and Guilloten, 1989).

Thus, the objective of this study was to verify whether the replacement of corn with molasses or glucose syrup in the starter concentrate of dairy calves may cause negative effects related to gut diseases and metabolic disorders such as dehydration and metabolic acidosis.

\section{Materials and Methods}

The study was conducted in the Experimental Calf Section of the Animal Science Department of Escola
Superior de Agricultura "Luiz de Queiroz", Piracicaba, São Paulo, Brazil from December, 2011 to June, 2012. All procedures performed involving animals were in accordance with the ethical standards of the University. Thirty-two Holstein calves, with average initial age of two weeks and average birth weight of $39 \mathrm{~kg}$, were utilized. Calves were fed $4 \mathrm{~L} / \mathrm{d}$ of high quality colostrum, divided into two feedings until the second day of life. Animals were housed in individual shelters distributed in a grassy field, with free access to water and concentrate. Animals were fed $4 \mathrm{~L} / \mathrm{d}$ of milk replacer (Sprayfo Violeta ${ }^{\circledR}$ 20CP:16EE, 12.5\% solids, Sloten of Brazil Ltd., Santos, SP, Brazil) that were divided into two meals (7h00 and 17h00). The starter concentrate, formulated according to the experimental treatment (Table 1), was provided daily and the daily intake was monitored through the weight of orts. The weaning was performed abruptly at the eighth week of life when the experimental period ended.

Table 1. Ingredients e chemical composition of starter concentrate with different levels of molasses and glucose syrup replacing corn

\begin{tabular}{|c|c|c|c|c|}
\hline \multirow[b]{2}{*}{ Ingredients, \% MS } & \multicolumn{4}{|c|}{ Treatments $^{(\dagger)}$} \\
\hline & $0 \mathrm{MO}$ & $5 \mathrm{MO}$ & $10 \mathrm{MO}$ & $5 \mathrm{GS}$ \\
\hline Corn & 65.0 & 60.0 & 55.0 & 60.0 \\
\hline Soybean meal & 24.0 & 24.0 & 23.0 & 24.0 \\
\hline Molasses & 0.0 & 5.0 & 10.0 & 0.0 \\
\hline Glucose syrup & 0.0 & 0.0 & 0.0 & 5.0 \\
\hline Soybean hulls & 10.0 & 10.0 & 11.0 & 10.0 \\
\hline Minerals an dvitamins $s^{(\ddagger)}$ & 1.0 & 1.0 & 1.0 & 1.0 \\
\hline \multicolumn{5}{|l|}{ Chemical composition } \\
\hline Dry matter, $\mathrm{g} / \mathrm{kg}$ & 880.0 & 874.0 & 878.0 & 879.0 \\
\hline Mineral matter, $g / k g$ & 42.0 & 47.0 & 47.0 & 41.0 \\
\hline Crude protein, $\mathrm{g} / \mathrm{kg}$ & 196.0 & 199.0 & 193.0 & 195.0 \\
\hline Ether Extract, $\mathrm{g} / \mathrm{kg}$ & 41.0 & 41.0 & 34.0 & 39.0 \\
\hline Neutral detergent fiber, $\mathrm{g} / \mathrm{kg}$ & 164.0 & 188.0 & 187.0 & 169.0 \\
\hline Acid detergent fiber, $\mathrm{g} / \mathrm{kg}$ & 94.0 & 108.0 & 115.0 & 103.0 \\
\hline Lignin, g/kg & 7.5 & 7.2 & 9.4 & 8.2 \\
\hline Non fiber carbohydrates, $\mathrm{g} / \mathrm{kg}$ & 557.0 & 526.0 & 540.0 & 556.0 \\
\hline Metabolizable energy, $(\mathrm{Mcal} / \mathrm{kg} \mathrm{MS})^{(\S)}$ & 3.0 & 3.0 & 3.0 & 3.0 \\
\hline Gain net energy, $(\mathrm{Mcal} / \mathrm{kg} \mathrm{MS})^{(\S)}$ & 1.9 & 1.9 & 1.9 & 1.9 \\
\hline Calcium, $\mathrm{g} / \mathrm{kg}(\S)$ & 4.0 & 4.0 & 5.0 & 4.0 \\
\hline Phosphorus, g/kg ${ }^{(\S)}$ & 3.0 & 3.0 & 4.0 & 2.0 \\
\hline
\end{tabular}

(†) 0 MO: Without replacement of corn by sugarcane molasses or glucose syrup; $5 \mathrm{MO}$ : Replacement of $5 \%$ of corn by sugarcane molasses; 10 MO: Replacement of $10 \%$ of corn by sugarcane molasses; 5 GS: Replacement of $5 \%$ of corn by glucose syrup; ${ }^{(*)}$ Minerals and vitamins composition: Ca 16.8\%; P 4.2\%; S 2.3\%; Na 11.6\%; Cl 8.0\%; Mg 2.4; Co 38.2 ppm; Cu 343 ppm; I 30.2 ppm; Fe 578.2 ppm; Mn 1146.4 ppm; Se 15.5 ppm; Zn 1176.2 ppm; Vit. A 68,760 UI/kg; Vit. E 764 UI/kg; Vit. D 57,300 UI/kg. ${ }^{(\S)}$ Estimated value by NRC (2001)

Table 2. Diarrhea occurrence description

\begin{tabular}{|c|c|c|c|c|}
\hline & \multicolumn{4}{|c|}{ Treatments $^{(\dagger)}$} \\
\hline & $0 \mathrm{MO}$ & $5 \mathrm{MO}$ & $10 \mathrm{MO}$ & $5 \mathrm{GS}$ \\
\hline Diarrheic calves, $n$ & 6 & 9 & 8 & 7 \\
\hline Diarrhea recurrence, calves & 1 & 0 & 0 & 1 \\
\hline Average age of diarrhea occurrence, $d$ & $15.0 \pm 4.16$ & $16.3 \pm 9.06$ & $17.9 \pm 4.36$ & $24.7 \pm 20.68$ \\
\hline
\end{tabular}

(†) $0 \mathrm{MO}$ : Without replacement of corn by sugarcane molasses or glucose syrup; $5 \mathrm{MO}$ : Replacement of $5 \%$ of corn by sugarcane molasses; 10 MO: Replacement of $10 \%$ of corn by sugarcane molasses; 5 GS: Replacement of $5 \%$ of corn by glucose syrup 
The evaluations of fecal score of all animals were performed every morning according to Larson et al. (1977) and were classified according to the fluidity: (1) When normal and solid; (2) when feces had a pasty consistency but a generally healthy aspect; (3) when feces had an aqueous consistency and were considered to be diarrhea; (4) when feces had a fluid consistency. Diarrhea cases were considered when the fecal score was greater than 3. Animals that were considered to have diarrhea were monitored for a three day period to evaluate the color, consistency and fecal components as described by the same authors. During this period, rectal temperature, heart rate and respiratory rate were measured at 7h00, 12h00 and 19h00. Also, the clinical sign scores were evaluated in diarrheic calves according to methodology adapted from Kasari and Naylor (1986). The score for each variable was added to obtain a minimum score of zero for healthy calves and a maximum score of 12 for debilitated calves presenting with bad clinical signals. A description of diarrhea occurrence, recurrence and duration is presented in Table 2.

Environment temperature, air humidity and wind speed were measured since thermal comfort indexes interfere with the physiological parameters. To verify the peak of heat stress for the animals, the Humidity and Temperature Index (HTI) was calculated by using the equation described by Thom (1959): HTI $=(0.8 \times \mathrm{T}+$ $(\mathrm{AH} / 100) \times(\mathrm{T}-14.4)+46.4)$, where $\mathrm{T}=$ ambient temperature $\left({ }^{\circ} \mathrm{C}\right)$ and $\mathrm{AH}=$ Air Humidity $(\%)$.

Also, during the three days after the diarrhea diagnosis, blood samples were collected two hours after the milk replacer morning feeding by using tubes with sodium fluoride as an antiglicolytic and Ethylenediamine Tetraacetic Acid (EDTA) as an anticoagulant, or tubes containing sodium heparin, according to the analysis. Immediately after the blood collection, the samples in the sodium heparin tubes were evaluated for glucose, hematocrit $(\mathrm{Hct} \%)$, blood gas and concentrations of sodium $(\mathrm{Na})$, potassium $(\mathrm{K})$, chloride $(\mathrm{Cl})$, blood $\mathrm{pH}$, carbon dioxide pressure $\left(\mathrm{PCO}_{2}\right)$, Plasma Urea Nitrogen (PUN), Hemoglobin $(\mathrm{Hb})$, bicarbonate $\left(\mathrm{HCO}_{3}{ }^{-}\right)$, base excess $\left(\mathrm{BE}_{\mathrm{ecf}}\right)$ and anion gap by using a portable blood analyzer I-Stat ${ }^{\circledR}$. Samples from the fluoride tube were centrifuged at $2,000 \times \mathrm{g}$ for $20 \mathrm{~min}$ at a temperature of $4^{\circ} \mathrm{C}$ and harvested plasma was frozen for further analyses. Determination of plasma glucose, total protein, albumin and L-lactate were performed by using commercial enzymatic kits from LABTEST Diagnóstica S.A. For the determination of $\beta$-hydroxy butyrate a commercial enzymatic kit from RANDOX LaboratoriesLife Sciences Ltd., was utilized. The analyses of total plasma lactate concentration were performed based on the methodology described by Pryce (1969). The determination of D-lactate was obtained by calculating the difference between the results of total plasma lactate $(\mathrm{mg} / \mathrm{dL})$ and plasma L-lactate $(\mathrm{mg} / \mathrm{dL})$.

The experimental design was a randomized block that considered the birth weight and birth date of the animal. For binomial variables, Generalized Linear Models were utilized with the logit link function (GLIMMIX). Data of blood parameters and the evaluations of clinical signs were analyzed in a factorial design by using the procedure MIXED of SAS (1991). To compare the effect of the means, the Student t-test was utilized, where the means were estimated through the minimum square method with a significance level of $5 \%$.

\section{Results}

The average environment temperature during the experimental period was $22^{\circ} \mathrm{C}\left(\mathrm{T}_{\min } 5.4^{\circ} \mathrm{C}\right.$ and $\mathrm{T}_{\text {max }}$ $36.8^{\circ} \mathrm{C}$ ) and the average Temperature and Humidity Index (THI) was 70.8 (THI $_{\min } 61.3$ and $\mathrm{THI}_{\max }$ 76.1). The addition of molasses and glucose syrup in the starter concentrate did not affect $(p<0.05)$ the fecal score of the animals during the liquid-feeding phase (Fig. 1). The clinical score and physiological parameters were not affected by the inclusion of molasses and glucose syrup in the starter concentrate and there was no effect of days on clinical score and physiological parameters. However, there was a difference $(\mathrm{p}<0.0001)$ among time of the day (7h00, $12 \mathrm{~h} 00$ and 19h00) during which the animals were submitted to the evaluations (Table $3)$. Hematocrit was affected $(p<0.05)$ by the composition of the starter concentrate, with the highest value observed for calves fed 10\% MO (Table 4). There was no observed effect of the starter concentrate composition on blood gas analyses or electrolyte evaluations of animals during diarrhea cases.

Table 3. Average values of three days of evaluation score of clinical signs and physiological parameters of diarrhea calves fed concentrate containing molasses or glucose syrup replacing corn

\begin{tabular}{|c|c|c|c|c|c|c|c|c|c|}
\hline & \multicolumn{4}{|c|}{ Treatments $^{(\dagger)}$} & \multicolumn{5}{|c|}{$\mathrm{P}<(\S)$} \\
\hline & $0 \mathrm{MO}$ & $5 \mathrm{MO}$ & $10 \mathrm{MO}$ & $5 \mathrm{GS}$ & $\mathrm{SEM}^{(\ddagger)}$ & $\mathrm{T}$ & $\mathrm{D}$ & $\mathrm{H}$ & TxDxH \\
\hline Clinical score $(0-12)$ & 2.69 & 3.28 & 3.51 & 2.79 & 0.80 & 0.85 & 0.79 & $<0.0001$ & 0.89 \\
\hline Rectal $\mathrm{T}^{\circ} \mathrm{C}$ & 39.10 & 39.40 & 39.50 & 39.10 & 0.15 & 0.08 & 0.84 & $<0.0001$ & 0.11 \\
\hline Respiratory rate (rpm) & 36.20 & 41.90 & 46.30 & 34.00 & 3.74 & 0.09 & 0.18 & $<0.0001$ & 0.60 \\
\hline Heart rate (bpm) & 104.20 & 106.90 & 111.20 & 98.20 & 4.11 & 0.15 & 0.46 & $<0.0001$ & 0.78 \\
\hline
\end{tabular}

(†) 0 MO: Without replacement of corn by sugarcane molasses or glucose syrup; $5 \mathrm{MO}$ : Replacement of $5 \%$ of corn by sugarcane molasses; 10 MO: Replacement of $10 \%$ of corn by sugarcane molasses; 5 GS: Replacement of $5 \%$ of corn by glucose syrup; (*) SEM: Standard error of the mean; ${ }^{\left({ }_{1}\right.} \mathrm{T}=$ treatment effect; $\mathrm{D}=$ day effect; $\mathrm{H}=$ Time of evaluation effect; $\mathrm{TxDxH}$ treatment, day and time interaction 
Table 4. Blood gas and electrolytes analysis assessment and plasma biochemical metabolites of diarrheic calves fed concentrate containing molasses or glucose syrup replacing corn

\begin{tabular}{|c|c|c|c|c|c|c|c|c|}
\hline & \multicolumn{4}{|c|}{ Treatament $^{(1)}$} & \multirow[b]{2}{*}{$\mathrm{SEM}^{(\ddagger)}$} & \multicolumn{3}{|c|}{$\mathrm{P}<(\S)$} \\
\hline & $0 \mathrm{MO}$ & $5 \mathrm{MO}$ & $10 \mathrm{MO}$ & $5 \mathrm{GS}$ & & $\mathrm{T}$ & $\mathrm{D}$ & $\mathrm{TxD}$ \\
\hline Hematocrit (\%) & $23.0^{\mathrm{a}}$ & $26.4^{\mathrm{b}}$ & $28.9^{c}$ & $25.1^{b}$ & 1.66 & 0.04 & 0.16 & 0.03 \\
\hline $\mathrm{pH}$ & 7.31 & 7.35 & 7.31 & 7.36 & 0.01 & 0.26 & 0.40 & 0.90 \\
\hline $\mathrm{HCO}_{3}(\mathrm{mmol} / \mathrm{L})$ & 25.94 & 29.70 & 27.43 & 29.68 & 1.52 & 0.29 & 0.13 & 0.44 \\
\hline $\mathrm{PCO}_{2}(\mathrm{mmHg})$ & 50.6 & 53.5 & 53.9 & 52.4 & 1.97 & 0.65 & 0.79 & 0.77 \\
\hline $\mathrm{K}(\mathrm{mEq} / \mathrm{L})$ & 4.84 & 4.94 & 5.06 & 4.83 & 0.10 & 0.39 & 0.99 & 0.93 \\
\hline $\mathrm{Na}(\mathrm{mEq} / \mathrm{L})$ & 135.5 & 137.2 & 134.3 & 135.7 & 0.98 & 0.23 & 0.22 & 0.29 \\
\hline $\mathrm{Cl}(\mathrm{mmol} / \mathrm{L})$ & 100.6 & 99.9 & 98.6 & 97.2 & 1.10 & 0.17 & 0.59 & 0.33 \\
\hline Anion Gap (mmol/L) & 13.90 & 12.63 & 13.46 & 13.54 & 0.50 & 0.32 & 0.14 & 0.46 \\
\hline $\mathrm{BE}_{\mathrm{ecf}}(\mathrm{mmol} / \mathrm{L})$ & -0.25 & 4.14 & 1.25 & 4.18 & 1.78 & 0.28 & 0.14 & 0.45 \\
\hline $\mathrm{Hb}(\mathrm{g} / \mathrm{dL})$ & 7.87 & 9.34 & 10.17 & 8.61 & 0.91 & 0.36 & 0.86 & 0.30 \\
\hline$\beta$-HBA (mmol/L) & 0.057 & 0.074 & 0.058 & 0.050 & 0.008 & 0.25 & 0.95 & 0.29 \\
\hline Glucose (mg/dL) & 79.89 & 85.43 & 84.45 & 80.21 & 3.12 & 0.47 & 0.51 & 0.78 \\
\hline Total protein $(\mathrm{g} / \mathrm{dL})$ & 6.83 & 7.09 & 6.70 & 6.66 & 0.32 & 0.77 & 0.11 & 0.50 \\
\hline Albumin (g/dL) & 3.41 & 3.08 & 2.91 & 3.03 & 0.12 & 0.06 & 0.70 & 0.84 \\
\hline PUN (mg/dL) & 7.61 & 6.83 & 8.20 & 5.75 & 1.02 & 0.44 & 0.17 & 0.80 \\
\hline Total lactate $(\mathrm{mg} / \mathrm{dL})$ & 16.94 & 14.62 & 19.34 & 14.92 & 2.98 & 0.09 & 0.24 & 0.19 \\
\hline D-Lactate $(\mathrm{mg} / \mathrm{dL})$ & 6.49 & 4.68 & 7.58 & 4.36 & 104 & 0.67 & 0.52 & 0.22 \\
\hline L-Lactate (mg/dL) & 10.45 & 9.93 & 11.76 & 10.56 & 1.90 & 0.92 & 0.19 & 0.95 \\
\hline
\end{tabular}

(†) 0 MO: Without replacement of corn by sugarcane molasses or glucose syrup; $5 \mathrm{MO}$ : Replacement of $5 \%$ of corn by sugarcane molasses; 10 MO: Replacement of $10 \%$ of corn by sugarcane molasses; 5 GS: Replacement of $5 \%$ of corn by glucose syrup; ${ }^{(*)}$ SEM: Standard error of the mean; ${ }^{(\S)} \mathrm{T}=$ treatment effect; $\mathrm{D}=$ day effect; $\mathrm{TxD}=$ Treatment and day interaction; ${ }^{\mathrm{a}, \mathrm{b}, \mathrm{c}}$ Values in the same row without a common superscript letter are significantly different $(\mathrm{p}<0.05)$

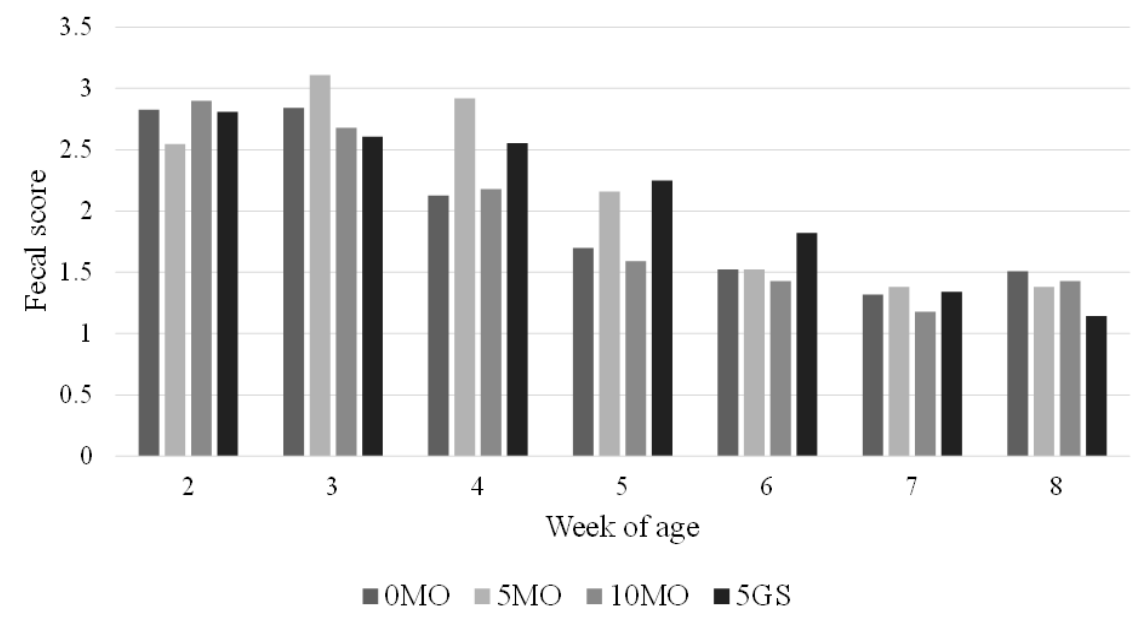

Fig. 1. Fecal Score of calves fed concentrate with molasses or glucose syrup replacing corn

\section{Discussion}

Considering the average environment temperature, animals were in thermal comfort since the upper critical temperature for calves is $25^{\circ} \mathrm{C}$ and the lower critical temperature is $13^{\circ} \mathrm{C}$ (Silva, 2000). However, at some points, the temperature was out of the comfortable margin and may have caused heat stress. According to Armstrong (1994), THI values up to 72 did not cause stress, however values from 72 to 78 represent mild stress. It should be emphasized that the animals were stressed at some moments during the day for most of the months and only in January, May and June of 2012 was the THI considered to be within the thermal comfort range for the animals.

Similar results in which the inclusion of molasses in the starter concentrate did not have an effect on fecal scores were reported by Lesmeister and Heinrichs (2005). On the other hand, in the study of Hill et al. (2008), the inclusion of 5\% molasses and $10 \%$ molasses $+1.5 \%$ glucose caused a significant increase in the fecal score of calves during the 6th, 7th and 8th weeks of age. In the present study, the greatest fecal scores were observed during the second and third weeks of age. 
According to the characteristics of diarrheic feces of the animals, an yellowish coloring in $69 \%$, grayish coloring in $11 \%$ and black coloring in $11 \%$ of the feces were observed; $71 \%$ had an aqueous consistency (score 3), $29 \%$ had a fluid consistency (score 4 ), $32 \%$ obtained a slightly offensive odor and $62 \%$ had a highly offensive odor in the feces of animals. Thus, based on the fecal characteristics it may be suggested that there was a greater prevalence of pathological agents such as Escherichia coli and corona virus (Millemann, 2009). Smith (2001) reports that besides these two pathogens, rotavirus, Cryptosporidium and coccidiosis (Eimeriabovis and E. zurernii) also caused yellowish colored diarrhea. However, the presence of pathogenic bacteria in feces was not investigated in the present study.

The highest clinical score was recorded during the periods where the THI was greater (Fig. 2), thereby emphasizing that there was no effect of the inclusion of molasses or glucose syrup in the starter concentrate that was provided for the animals. A clinical score above 6.5 indicates a sick clinical score (Nakagawa et al., 2007), which demonstrates that the animals had a healthy clinical score since the means of the treatments were below this value. The main symptoms that the calves with diarrhea presented with during the experimental period were a reduction in appetite, apathy, decrease in the suckling reflex and dehydration from light to moderate. However, there was no effect of the starter concentrate composition on these measures, so the replacement of corn with these byproducts did not change or intensify the symptoms of diarrheic animals.

The range in variation that is considered to be normal for Holstein calves for rectal temperature, respiratory rate per minute (rpm) and heart rate per minute (bpm) are between $38.0-39.5^{\circ} \mathrm{C}, 15-40 \mathrm{rpm}$ and from 60 to 120 bpm, respectively (El-Sheikh et al., 2012). Thus, it is possible to observe that the average rectal temperature and respiratory rate of the animals may be considered normal only in the measurements at $7 \mathrm{~h} 00$; however it was greater than that at $12 \mathrm{~h} 00$ and $19 \mathrm{~h} 00$ (Fig. 2). Even though the heart rate did not exceeded normal range, there was a difference among times, with greater values for the $12 \mathrm{~h} 00$ and $17 \mathrm{~h} 00$ evaluations (Fig. 2). Therefore, it is possible to correlate rectal temperatures above $39.5^{\circ} \mathrm{C}$, a respiratory rate above $40 \mathrm{rpm}$ and a more accelerated heart rate to climate factors and to individual shelters, excluding infections as a cause of hyperthermia. The respiratory and cardiovascular systems play a role in thermoregulation, as heat loss occurs by evaporative cooling (respiratory system) and vasodilatation increases the contact surface between blood and skin to dissipate heat (cardiovascular system). Thus, it is possible to understand the differences in heart rate and respiratory rate during the evaluated times. There was no interaction between time of day and starter concentrate composition $(p>0.05)$, which shows that the inclusion of molasses or glucose syrup did not alter these physiological parameters in diarrheic calves. The average values of hematocrit were within the reference ranges (Ramin et al., 2012), indicating that the animals did not suffer dehydration during the first three days of diarrhea. However, animals receiving the concentrate with the inclusion of $10 \%$ molasses achieved hematocrit average values close to the normal upper limit (29.55\%).

Although the inclusion of molasses and glucose syrup did not influence fecal scores, the increase in the average values of hematocrit can be explained by the increased water loss, which was associated with the levels of molasses in the concentrate. This ingredient is composed mainly of sucrose (NRC, 2001) and sucrase production is limited in newborn calves (Lesmeister and Heinrichs, 2005), which may worsen the diarrhea cases because of the increased osmotic pressure by the presence of this sugar in the intestine. Over the days, diarrheic calves increased water loss, which could be observed by the interaction between starter concentrate composition and day of evaluation (Table 4).

Through the analyses, it is possible to verify that there are some primary and differential acid-base disorders. However, according to the normal reference values for young calves $\left(\mathrm{pH}: 7.31-7.49, \mathrm{PCO}_{2}\right.$ : 46-56 $\mathrm{mm} \mathrm{Hg}, \mathrm{HCO}_{3}^{-}: 22-30 \mathrm{mEq} \mathrm{L}^{-1}$ and $\mathrm{BE}_{\text {ecf: }}-3$ to $7 \mathrm{mmol}$ $\mathrm{L}^{-1}$ ), it is possible to verify that there were no acid-base disorders, independent of the starter concentrate composition. Due to the period of data collection for blood gas analyses and the fact that the evaluation of electrolytes occurred over three days, it is possible that acidotic cases or acid-base disorders were not detected. Freitas (2009) analyzed 92 healthy and diarrheal heifers and observed a normal blood $\mathrm{pH}$ until the fourth day of evaluation, although at the seventh and tenth days, $67 \%$ and $100 \%$ of the animals presented with a $\mathrm{pH}$ below 7.31 , thus indicating a metabolic acidosis. It is possible that animals could have reached an acidotic condition after the evaluation period. However, after three days animals were treated with antibiotic when needed. Average values of $\mathrm{HCO}_{3}{ }^{-}(\mathrm{mmol} / \mathrm{L})$ and $\mathrm{PCO}_{2}(\mathrm{mmHg})$ are within the reference values, however presented a small decrease during the days of evaluation. Similar results were also found by Freitas (2009), who conclude that it is normal for diarrheic calves to loose $\mathrm{HCO}_{3}^{-}$ through their feces. There was a difference at the first day of evaluation $(\mathrm{p}<0.05)$ between calves fed $0 \% \mathrm{MO}$ and $5 \% \mathrm{MO}$; and on the third day $(\mathrm{p}<0.04)$ between calves fed $0 \% \mathrm{MO}$ and $5 \% \mathrm{GS}$ in relation to the values of $\mathrm{HCO}_{3}^{-}$. Generally, there was no negative effect from the inclusion of molasses or glucose syrup in the concentrate in relation to the discussed parameters of blood $\mathrm{pH}, \mathrm{HCO}_{3}^{-}(\mathrm{mmol} / \mathrm{L})$ and $\mathrm{PCO}_{2}(\mathrm{mmHg})$, which are essential data used to diagnose metabolic acidosis cases that arise as a consequence of diarrhea in calves (Walker et al., 1998). 

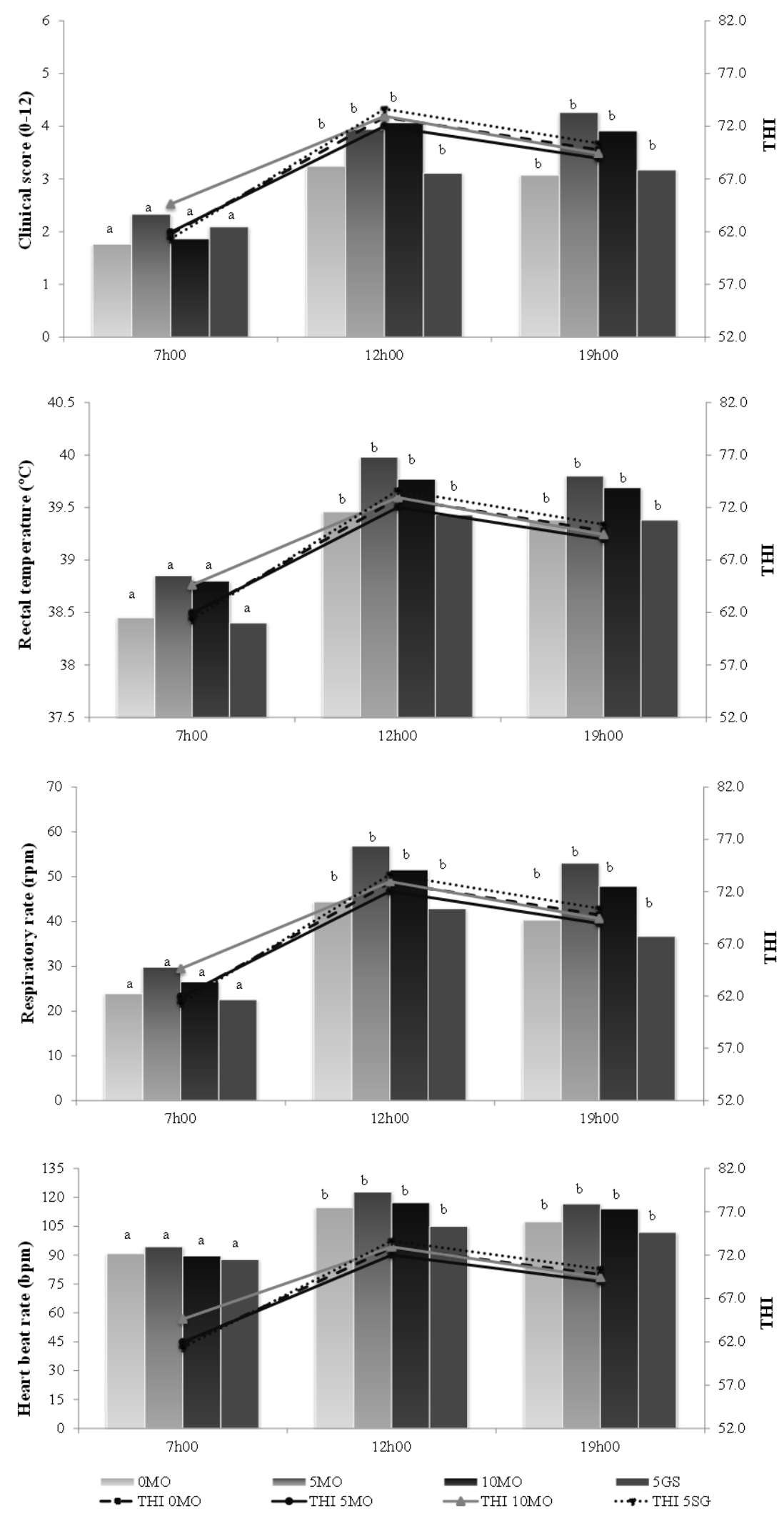

Fig. 2. Average of clinical score, rectal temperature, respiratory rate and heart rate of diarrheic calves fed concentrate with molasses or glucose syrup replacing corn 
Electrolytes were within the reference values, which reinforces the absence of dehydration in the diarrheic animals, independent from the starter concentrate composition. Potassium has a regulatory function in the acid-base balance of the body. In diarrheic calves, it is common to find cases of hyperkalemia (Maach et al., 1992). Sodium is considered to be the main cation of the extracellular fluid and together with chloride, it functions to maintain the osmotic pressure which is important for the water metabolism in the body and to regulate the acid-base balance (Houpt, 2006). The normal reference values of Anion Gap for Holstein calves until 1 month of

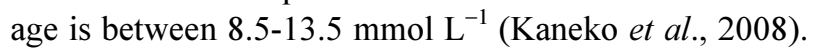
Only animals fed $0 \%$ MO presented values above that considered to be normal, which can indicate a light metabolic acidosis despite the fact that the values of $\mathrm{Na}$, $\mathrm{K}$ and $\mathrm{Cl}$ were within the range considered to be normal.

The starter concentrate composition with the inclusion of molasses or glucose syrup as a replacement for corn did not affect plasma biochemical parameters (Table 4). Also, there was no effect of day of evaluation or interaction of day after the diagnosis of diarrhea and starter concentrate composition. The $\beta$-HBA concentrations were low $(<0.1$ mmol $\mathrm{L}^{-1}$ ), indicating that the rumen of these animals were relatively undeveloped; also, these values suggest an absence of secondary ketosis from nutrient loss or insufficient feed intake. It is common to observe hypoglycemia in diarrheic calves (Kaneko et al., 2008); however, the glucose concentration of animals in the present study is within the normal value (Houpt, 2006). Dehydrated diarrheic calves presented plasma urea nitrogen concentrations above the range that is considered to be normal (healthy calves $4.65-7.68 \mathrm{mg} \mathrm{dL}^{-1}$ and severe cases 10.75-28.61 $\mathrm{mg} \mathrm{dL}^{-1}$; Seifi et al., 2006). Therefore, it can be stated that calves fed a starter concentrate with $10 \%$ MO presented values above those considered to be normal; however, these values did not exceed $10.75 \mathrm{mg}$ $\mathrm{dL}^{-1}$, which can suggest that these animals had a light acidotic disorder. The metabolic acidosis associated with diarrhea in calves can be aggravated due to the production and increase in the concentrations of lactic acids such as D-lactate and L-lactate in the body (Millemann, 2009). Plasma concentrations of lactate between 6 to $22 \mathrm{mg}$ $\mathrm{dL}^{-1}$, plasma concentrations of L-lactate up to $11.8 \mathrm{mg}$ $\mathrm{dL}^{-1}$ and D-lactate up to $3.9 \mathrm{mg} \mathrm{dL}^{-1}$ are considered to be acceptable (Kasari and Naylor, 1986). The average values of total lactate and L-lactate that were observed in diarrheic calves were within the values considered to be normal. However, the values of D-lactate were above those considered to be normal.

\section{Conclusion}

Increase in severity and/or metabolic changes in response to the inclusion of molasses and glucose syrup as a replacement for corn in the starter concentrate of dairy calves were not observed. However, a light acidosis may be pointed to animals fed the $10 \%$ molasses starter concentrate. Sugar cane molasses and glucose syrup may replace corn in the composition of starter concentrate without worsening metabolic changes in diarrheic dairy calves.

\section{Funding Information}

The authors wish to express their appreciation for the financial support provided by the Fundação de Amparo à Pesquisa do Estado de São Paulo (FAPESP) as a research grant.

\section{Author Contributions}

Marcelo Cezar Soares: Study conception and design, data collection, analysis and interpretation of data, manuscript writing and reviewing.

Carlos Eduardo Oltramari and Marília Ribeiro de Paula: Study conception and design, data collection.

Carolina Corrêa de Figueiredo Monteiro: Manuscript writing and reviewing.

Gerson Barreto Mourão: Study conception and design, analysis and interpretation of data.

Carla Maris Machado Bittar: Study conception and design, data collection, analysis and interpretation of data, manuscript writing and reviewing, final approval.

\section{Ethics}

This article is original and contains unpublished material. The corresponding author confirms that all of the other authors have read and approved the manuscript and no ethical issues involved.

\section{Conflict of Interest}

None of the authors has any conflict of interest to declare.

\section{References}

Armstrong, D.V., 1994. Heat stress interaction with shade and cooling. J. Dairy Sci., 77: 2044-2050. DOI: 10.3168/jds.S0022-0302(94)77149-6

El-Sheikh, A.K.R., H.M.S. Morsy, T.H.A., Abbas and W.M. Abdelzarik, 2012. Clinical and laboratory examinations of diarrhea and dehydration in newborn Friesian calves with special reference to therapy with hypertonic and isotonic solution. Life Sci. J., 9: 181-184.

Freitas, M.D., 2009. Avaliação dos parâmetros clínicios e laboratoriais de bezerras com diarreia neonatal naturalmente adquiridas. Dissertação (Mestrado em Ciência Animal)- Escola de Veterinária, Universidade Federal de Minas Gerais, Belo Horizonte. 
Hill, T.M., H.G. Bateman, J.M. Aldrich and R.L. Schlotterbeck, 2008. Effects of feeding different carbohydrate sources and amounts to young calves. J. Dairy Sci., 91: 3128-3137. DOI: $10.3168 /$ jds.2007-0950

Houpt, T.R., 2006. Equilibrioácido-Básico. In: Dukes Fisiologia Dos Animais Domésticos, M.J. Swenson and W.O.O. Reece (Eds.), Guanabara Koogan, Rio de Janeiro, pp: 147-160.

Kasari, T.R. and J.M. Naylor, 1986. Further studies on the clinical features and clinicopathological findings of a syndrome of metabolic acidosis with minimal dehydration in neonatal calves. Canad. J. Vet. Res., 50: 502-508. PMID: 3024795

Kaneko, J.J., J.W. Harvey and M.L. Bruss, 2008. Clinical Biochemistry of Domestic Animal. 6th Edn., Academic Press, San Diego, ISBN-10: 012370491X, pp: 916.

Larson, L.L., F.G. Owen, J.L. Albright, R.D. Appleman and R.C. Lamb et al., 1977. Guidelines toward more uniformity in measuring and reporting calf experimental data. J. Dairy Sci., 60: 989-991. DOI: $10.3168 / \mathrm{jds} . S 0022-0302(77) 83975-1$

Lesmeister, K.E. and A.J. Heinrichs, 2005. Effects of adding extra molasses to a texturized calf starter on rumen development, growth characteristics and blood parameters in neonatal dairy calves. J. Dairy Sci., 88: 411-418. DOI: $10.3168 /$ jds.S0022-0302(05)72702-8

Lesmeister, K.E., P.R. Tozer and A.J. Heinrichs, 2004. Development and analysis of a rumen tissue sampling procedure. J. Dairy Sci., 87: 1336-1344. DOI: $10.3168 /$ jds.S0022-0302(04)73283-X

Maach, L., H.D. Gründer and A. Boujija, 1992. Klinische und hämatologische untersuchungen bei schwarzbuntenan durchfall erkrankten neugeborenen aufzuchtkälbern in Marokko. Deutsche Tierarztliche Wochenschrift, 99: 133-140.

Millemann, Y., 2009. Diagnosis of neonatal calf diarrhea. Revue Méd. Vet., 160: 404-409.
Nakagawa, M., K. Suzuki and K. Tagushi, 2007. Relationship between depression score and acidbase status in Japanese black calves with diarrhea. J. Vet. Med. Sci., 69: 549-552. DOI: $10.1292 /$ jvms.69.549

NRC, 2001. Nutrient Requirements of Dairy Cattle. 1st Edn., National Research Council, Washington, D.C.

Pryce, J.D., 1969. A modification of the BarkerSummerson method for the determination of lactic acid. Analyst, 94: 1151-1152. DOI: 10.1039/AN9699401151

Ramin, A.G., S. Asri-Rezaei, K. Paya, Z. Eftekhari and M. Jelodary et al., 2012. Evaluation of anemia in calves up to 4 months of age in Holstein dairy herds. Vetscan, 7: 87-92.

Seifi, H., M. Mohri, E. Shoorei and N. Farzaneh, 2006. Using haematological and serum biochemical findings as prognostic indicators in calf diarrhoea. Comparative Clin. Pathol., 15: 143-147. DOI: $10.1007 / \mathrm{s} 00580-006-0620-8$

SAS, 1991. SAS user guide. Statistics, SAS Institute.

Silva, R.G., 2000. Introdução à bioclimatologia animal. Nobel, São Paulo.

Smith, D., 2001. Management practices minimize risk of scours outbreak. Angus J., 12: 48-50.

Thom, E.C., 1959. The discomfort index. Weatherwise, 12: 57-60. DOI: 10.1080/00431672.1959.9926960

Toullec, R. and P. Guilloteau, 1989. Research into the Digestive Physiology of the Milk-Fed Calf. In: Nutrition and Digestive Physiology in Monogastric Farm Animals, Van Weerden, E.J. and J. Huisman (Eds.), Pudoc, Wageningen, pp: 37-37.

Walker, P.G., P.D. Constable, D.W. Morin, J.K. Drackley and J.H. Foreman et al., 1998. A reliable, practical and economical protocol for inducing diarrhea and severe dehydration in the neonatal calf. Canad. J. Vet. Res., 62: 205-213. PMID: 9684050 